\title{
John Fletcher of Corpus Christi College: New Records of His Early Years
}

Little is known for certain about John Fletcher's birth and college education. The earliest information comes from Humphrey Moseley, the London stationer, who first provided some pieces of biographical information roughly twenty years after Fletcher's death. In 1647, Moseley published Comedies and Tragedies Written by Francis Beaumont and Iohn Fletcher and, in 'the stationer to the readers', made brief reference to the age of the playwright at his death: 'Mr. Beaumont ... dyed young, for (which was an invaluable losse to this Nation) he left the world when hee was not full thirty yeares old. Mr. Fletcher survived, and lived till almost fifty; whereof the World now enjoyes the benefit'. 'Almost fifty' could in all honesty mean any age past forty-five, ie, nearer to fifty than to forty; however, some grounds indicate that Moseley intended to pinpoint Fletcher's age at forty-nine. Moseley prefixed Comedies and Tragedies with a portrait of Fletcher and inscribed onto this picture a record of his death: 'Obijt 1625 Ætat: 49'. According to this inscription, the playwright's birth can be dated 1575 or 1576 . Although his source is difficult to pin down, Moseley may have learned about Fletcher's death either from some members of the King's Men or from friends of the playwright, judging from his explanation as to where he acquired the picture of Fletcher: 'this figure of Mr. Fletcher was cut by severall Originall Pieces, which his friends lent me, but withal they tell me, that his unimitable Soule did shine through his countenance in such Ayre and Spirit, that the Painters confessed it, was not easie to expresse him.'2 Moseley and his contemporaries seem to have considered this inscription reliable; in fact, no one challenged the authenticity of 'Obijt 1625 Ætat: 49' before Alexander Dyce.

Moseley's record goes further than mere dates, however, since he also offers a brief comment on the playwright's university education: 'It becomes not me to say (though it be a knowne Truth) that these Authors had not only High unexpressible gifts of Nature, but also excellent acquired Parts, being 
furnished with Arts and Sciences by that liberall education they had at the Vniversity, which sure is the best place to make a great Wit understand it selfe. ${ }^{3}$ Fletcher's college affiliation is not specified here, but John Aubrey says, albeit without citing a source, that 'I thinke they [ie, Beaumont and Fletcher] were both of Queen's College in Cambridge. ${ }^{4}$ This information might be just one of the deficiencies common in Aubrey's account; alternatively, it might suggest, as Hilton Kelliher shows, the origin of the friendship between Beaumont and Fletcher. ${ }^{5}$ In any case, certainly Fletcher's contemporaries widely regarded him as a university-trained playwright.

Other sources provide further detail. While Moseley tells readers nothing about Fletcher's father, one of the Laudian contributors to the works of Beaumont and Fletcher, John Berkenhead, says, in his panegyric poem:

And as thy thoughts were cleare, so, Innocent;

Thy Phancy gave no unswept Language vent;

Slaunderst not Lawes, prophan'st no holy Page,

(As if thy Fathers Crosier aw'd the Stage).

$\cdots$

Miter and Coyfe here into One Piece spun,

BEAVMONT a Judge's, This a Prelat's sonne.

What strange Production is at last displaid,

(Got by Two Fathers, without Female aide)

Behold, two Masculines espous'd each other,

Wit and the World were born without a Mother. ${ }^{6}$

The information about Fletcher's noble paternity seems to have been especially important for Berkenhead, a participant in Moseley's aesthetic venture, in order to encourage royalist textual reproduction. ${ }^{7}$ In Berkenhead's royalist poetics, the legal and ecclesiastical authority of the poets' fathers harmonized perfectly with the legitimate authorship of the dramatic works begotten 'by Two Fathers, without Female aide'. Although Berkenhead says nothing definite about the identity of this prelate or about the source of his information, Fletcher's lofty lineage seems to have been a matter of common knowledge at that time. Berkenhead's statement was confirmed and expanded upon by Thomas Fuller, a moderate royalist churchman, who described the playwright in his posthumous The Worthies of England (1662) as follows: 'JOHN FLETCHER Son of Richard Fletcher D. D. was (as by proportion of time is collectible) born in this County [ie, Northamptonshire], before his Father 
was Bishop of Bristol or London, and whilst as yet he was Dean of Peterborough'. ${ }^{8}$ Gerald Langbaine, a biographer and critic, agreed with Fuller about the identity of the playwright's father as a bishop of London, as well as with Moseley about the playwright's death at the age of forty-nine. Langbaine says in his An Account of the English Dramatick Poets (1691) that:

He was Son to the Eminent Richard Fletcher, created Bishop of Bristol, by Queen Elizabeth An. 1559. and by her preferr'd to London, 1593. He died in London of the Plague in the First Year of King Charles the Martyr, 1625. being Nine and fourty Years of Age, and was bury'd in St. Mary Overies Church in Southwarke.?

As for the playwright's university career, to which Moseley referred briefly, Robert Masters, about a half-century later, attempted to trace the tracks of Fletcher in the college archives. In The History of the College of Corpus Christi (1753), he inferred from the evidence he had gathered that:

JOHN FLETCHER the Son of the Bishop, is said to have been born in Northamptonshire, whilst his Father was Dean of Peterborough, and to have been educated in this College; but as this does by no means correspond with his Age at the time of his Death; so 'tis more probable he was a Native of London, a Person of that Name and Place being admitted Pensioner here under the care of Mr. Dawson 15 Oct. 1591; when he must have been about fifteen years of Age, the usual time of Admission in those days. ${ }^{10}$

Masters rightly points out Fuller's error in dating the birth of the poet to the time of his father's tenure as dean of Peterborough (1583-9). He does more, however, than correct what has gone before; he provides detailed information about one John Fletcher of Corpus Christi College. Since Bishop Richard Fletcher was once a fellow of, and a generous donor to, the college, naturally Masters suspected the scholar of being the bishop's son and, more specifically, the poet. And yet the lack of firm evidence supports Nina Taunton's doubt as to the reliability of Masters, 'who', she argues, 'does not in any case give a reference source for his assertions.' ${ }^{11}$ Masters, nevertheless, is very specific in his description not only of the admission date but also of the scholar's supervisor, Ralph Dawson, who came from London and held a fellowship at Corpus Christi College from 1586 to $1597 .{ }^{12}$ In any case, evidently Robert Masters laid the foundation for the idea that John Fletcher, the son of the bishop, was a Corpus Christi graduate. 
Alexander Dyce was the first to become entangled with the inconsistencies inherent in this assumption. He found in the parish register of Rye, Sussex, a baptismal entry for 'John the son of Mr. Richard Flecher mynister' on 20 December $1579 .{ }^{13}$ Richard Fletcher, after his marriage in Cranbrook in May 1573, and having assisted in his father's ministry there, was fully engaged as 'preacher of the word of God in the church at Rye' from September 1574 to late 1580 or $1581 .{ }^{14}$ During this ministry, Richard seems to have resided in Rye with his family. In May 1576, the mayor and jurats of Rye testified in a certificate to the bishop of Chichester that Richard Fletcher 'being called hither of such as have the dealing in that behalf, to preach in the church of Rye, hath administered the sacraments as becomes a good minister of Jesus Christ and no less in the other life amongst us visiting our sick with diligence and doing his duty to the good example of the people'. ${ }^{15}$ He possibly gave up the living of Rye around 1583, when the deanery of Peterborough was conferred upon him, and then removed his family to Cranbrook. His wife, Elizabeth, had given birth to four children in succession at Rye - Nathaniel (1575), Theophilus (1577), Elizabeth (1578), and John (1579) — and to two more at Cranbrook - Thomas (1582) and Sara (1584). ${ }^{16}$ The discovery of the baptismal entry for John Fletcher led Dyce to conclude that the playwright was born in Rye and died at the age of forty-five. In drawing this conclusion, however, Dyce had to face a new problem, for this baptismal entry was clearly at odds with Moseley's (as well as Langbaine's) testimony that the playwright died at the age of forty-nine. Moreover, Dyce was required to accept - if his theory were correct - the idea that Fletcher was admitted to Corpus Christi College when he was less than twelve years old.

Dyce's solution to this problem was eclectic. Regarding the date of birth he rejected Moseley's suggestion, based on the baptismal date of John Fletcher of Rye: 'His biographers were led into the error of stating that he was born in 1576 by the information of the inscription on his portrait, prefixed to the folio of 1647, - "Obiit 1625. Ætat. 49"'. ${ }^{17}$ At the same time, Dyce asserted that Fletcher was admitted to Corpus Christi 'at a very early age: and he might have been described as "of London," because he had resided there with his father, who, after rising to the bench, spent much time in the metropolis', thereby accepting the Moseley-Masters line of thought. ${ }^{18}$ At this point, a few other alternatives were available to Dyce to avoid the difficulty of accepting that Fletcher came to college at such a young age: for instance, Dyce could have relinquished the very notion that Fletcher had a university career at 
all; equally, he could have drawn upon Moseley's account to cast doubt on the Berkenhead-Fuller identification of the poet as the bishop's son. Dyce proceeded without further careful scrutiny, however, and persisted with his eclectic hypothesis, which many eminent Fletcher scholars have supported to date. ${ }^{19}$

Dyce's explanation now warrants reconsideration. This is not to say that Fletcher's early admission to college would have been impossible: Francis Beaumont, for example, matriculated from Broadgates Hall (now Pembroke), Oxford, with his brothers at the age of twelve. Statistical analysis provided by Lawrence Stone, however, reveals that such young scholars were not particularly common at that time, ${ }^{20}$ and so critical skepticism about Fletcher's early beginnings to his university career is entirely understandable. E.K. Chambers points out that the playwright 'seems too young for the John Fletcher of London who entered Corpus Christi, Cambridge, in 1591'. ${ }^{21}$ More specifically, Taunton has recently suggested that even though 'Richard Fletcher (bishop of London and father of the playwright) was President of Corpus Christi, Cambridge, and bestowed gifts upon that college, it does not seem likely that his son John followed him there. ${ }^{22}$ This presumption seems to have considerable validity, although Taunton is somewhat hasty in concluding that 'there is no reference in the University records to a John Fletcher having been admitted to Corpus Christi College in 1591 or shortly thereafter'. Now, by drawing attention to a previously unnoticed document found among the university records, I would like to clarify the issues clouding the university career of John Fletcher of Corpus Christi College and suggest that some difficulty remains in identifying this Corpus Christi man with John Fletcher of Rye, the bishop's son.

At the time in question, the community of Corpus Christi College consisted of more than 100 students, and was such a relatively small and tightknit society that it could foster intimate contact and interdependence among its members. When the mutual confidence of the members eroded, however, the community could become a hotbed of violence and slander. This two-facedness is frequently evident in the Act Books of the vice-chancellor's court, which exercised jurisdiction over the university and which handled a wide range of legal business, including personal lawsuits brought by fellows and scholars. ${ }^{23}$ An incident which occurred on 13 October 1595 between Ralph Dawson, BD, a fellow of Corpus Christi, and Thomas Field, MA, of the same college, seems a typical case. The account of this incident merits rehearsal in full, because it sheds light on the identity of John Fletcher, 
helping us to escape the inconsistencies and problems that have blighted previous efforts to establish his identity. ${ }^{24}$

Thomas Field, after having obtained his MA in 1591, stayed on at the college for four years to pursue the next stage of his studies. He may have acquired academic and financial assistance from Ralph Dawson, his former tutor: in fact, Field was able to obtain a loan of a considerable sum from Dawson 'by the space of one yere ... vntill aboute the xvth or xvjth daye of October', 1595, and was even allowed to use a study in Dawson's 'vpper chamber', that is, a room in the roof space above Dawson's first-floor room. ${ }^{25}$ In October 1595, Field secured the vicarage of Babraham, a village six miles from Cambridge, and there took up his residence. Field's difficulty in repaying Dawson, however, seems to have put an end to Dawson's personal favour and their fraternal relationship. On the afternoon of 13 October, with the due date for repayment of the loan impending, Field stopped by the college for some reason (probably to contrive a way to raise money or to pack for removal), and spent his time, not in the study of Dawson's upper chamber, but in the first-floor room of Nicholas Martin, another fellow of Corpus Christi and Field's close friend. ${ }^{26}$

Meanwhile, Dawson, who was then walking in the courtyard of the college, sent for Nicholas Martin and said, 'Mr Martin, I vnderstande that $\mathrm{Mr}$ ffeilde is in your Chameber, whoe is indebted vnto me, and hathe greatlie Iniuried me besides, I woulde be lothe to ... come vppe into your Chamber ... withoute your consente'. Martin tersely replied, 'The dore is open and you (speakeinge to the said Mr Dawson) maye goe vppe if you will'. Thereupon, Dawson sent for the beadle, called Thomas Brookes, an executive officer under the vice-chancellor's mandate, and then, with this beadle, went up to the first-floor room of Nicholas Martin in order to take Field 'awaye from thence [to] $\wedge\lceil$ vnto or before $\rceil \mathrm{Mr}$ Vicechauncellar to answere the sayd $\mathrm{Mr}$ Dawson in a cause of debte'. 27

Against these coercive measures, Field, far from being submissive, locked himself in Martin's chamber. After struggling for a while to break into the room, Dawson called for a smith's boy to have him wrench the door open. Martin, present at the scene, forbade the boy to do it; nevertheless, according to the deposition of Martin, 'then \& there the sayd Mr Dawson takeinge the tooles from the sayd Smithe boyes sayd yat he (predictus Dawson) would open the same studye doare him selfe'. Martin remonstrated with his colleague, saying: ' $\wedge\ulcorner\mathrm{Mr}$ Dawson $\urcorner \mathrm{I}$ thincke you cannot neither may you lawfully doe yt, and I wishe you to doe noe more then lawfully you may 
doe'. This admonition, however, fell on deaf ears, as Martin noted in his testimony:

And not withstandinge all this: the sayd Mr Dawson did then $\&$ there with a chisell \& a hammer vnnayle the hingells of the sayd studye doare, \& soe opened the same, and $\wedge\left\ulcorner^{\top}\right.$ then $\urcorner$ seeinge the sayd $\mathrm{Mr}$ ffeyeld there in the sayd studye and sayd to Mr Brookes the Bedell (whoe was then \& there all this while) thus: or the lyke in effecte: viz: nowe I haue opened the doare, and there is the partye (meaninge the sayd $\mathrm{Mr}$ ffyeld) doe what you haue to doe. ${ }^{28}$

As soon as he was dragged out of the room, Thomas Field was brought into the parlour of John Duport, the vice-chancellor and master of Jesus College, to make an apology for the debt. For Field to have to put up with such injuries to his reputation must have been unbearable. And no doubt because he was under such duress, in the presence of the vice-chancellor, Field dared to strike back by laying a charge against Dawson. ${ }^{29}$ Then, around five o'clock in the afternoon, John Duport sent for John Smith, the deputy to the university registrar, and requested him to 'record and inacte twoe Actes towcheinge and concerninge twoe seuerall actiones ... whereof the one was in causa Iniuriarum, and thother was in causa rei vendicacionis. ${ }^{30}$

Two causes of action were at issue. The first is in causa iniuriarum, that is, for the reason of an offence made against Field's good reputation. Considering the illegality of Dawson's actions, this cause seems to have been quite reasonable. Even more important is the second charge, in causa rei vendicacionis. To put it plainly, Field was demanding that Dawson return things which belonged to him. Very likely, Dawson's unlawful possession of those things, as well as his injuries to Field's credit, had made Field baulk at his treatment severely enough to take action. Now the case was altered, and Dawson was obliged to confess that:

he this respondent did finde in A Studdye in this respondents vpper chamber A greeke Lexicon in twoe volumes, [A peece of $S^{\prime} \mathrm{Dr}<\ldots>\mathrm{d}$ ] A comment of Aquine vppon Genesis, and another booke in folio covered with white lether, which $\lceil[\langle\ldots\rangle]\urcorner$ were the bookes of the sayd Thomas ffyeld. / And because this | sayd respondent fownd the sayd Studdye doare vnlocked and open; and alsoe for that the sayd Thomas ffyeld was then indebted vnto this sayd respondent in iiij li. iij. s. xj d. ob. for commons and syzinges and other matters! he this sayd respondent tooke the aforesayd bookes oute of the aforesayd Studdye as he thoughte by 
lawe he mighte doe, $\&$ the rather because the sayd Studdye was $\&$ ys his this sayd respondentes studdye. ${ }^{31}$

At what point did Dawson take Field's books from the study? Fortunately, a certain scholar happened to have witnessed his actions and, partly due to this scholar's testimony, Dawson had to acknowledge his fault before the vice-chancellor immediately on that day. That well-placed witness was none other than John Fletcher of Corpus Christi College.

According to the deposition of John Fletcher made on 23 December 1595, he had known 'the said Mr Dawson and Mr ffeilde here mencioned aboute these ffoure yeres last past and $\mathrm{Mr}$ Dawson longer'. Fletcher happened to 'see $\mathrm{Mr}$ Raphe Dawson fetche forthe of ... the studye 「 there $\rceil$ wherein $\mathrm{Mr}$ ffeilde latelie kepte certeine bookes' and 'see the $\wedge\lceil$ sayd $\urcorner$ studye doare of the said $\mathrm{Mr}$ ffeilde picked $\wedge\ulcorner$ open $\urcorner$ or opened by A smithe'. Fletcher seems unimpeachable here as a witness, because he was 'in $\mathrm{Mr} \ldots \wedge\ulcorner$ Dawsons vpper $\rceil$ Chamber in Bennett Colledge in Camebridge, wherein this deponente then kepte or remained' with Dawson's permission, as was Field. ${ }^{32}$

No document survives which reveals how the incident was settled; nevertheless, what most concerns us here is not the outcome of Field's lawsuit, but the personal information we can glean about this eye-witness himself. In the Deposition Books of the vice-chancellor's court, many deponents give their age, birthplace, profession, and so forth. Fortunately, for our purposes at least, the origins of John Fletcher can be found at the beginning of his deposition:

${ }^{\circ}$ Iohannes ffletcher ${ }^{\circ}$ in Artibus Bacchalaureus Scholaris Collegij Corporis christi in Alma Academia Cantabrigie, vbi moram fecit per spacium quatuor Annorum vel circiter, antea ap $u$ d London in comitatu Middlesexie ab incunabilis suis ibidemque oriundus, etatis xix Annorum vel circiter, libere (vt ait) condicionis, testis primus in hac causa examinatus deponit vt sequitur viz.

[John Fletcher, BA, a scholar of Corpus Christi College in the gracious university of Cambridge, where he has stayed for the space of four years or thereabouts, before which he was in London in the county of Middlesex from his infancy and born in the same place, nineteen years of age or thereabouts, of a free condition, as he says, having been examined as the first witness in this case, deposes as follows, viz.. ${ }^{33}$ 
This description reveals several important facts about John Fletcher of Corpus Christi. Given that he had been a student of the college for about four years by 23 December 1595, his admission to the college can be dated somewhere in the latter half of 1591. The fact that Fletcher was acquainted with Dawson for more than four years, and that he resided in the study of Dawson's upper chamber, strongly suggests that Fletcher had been under the care of this college fellow. Apparently, therefore, despite Robert Masters's lack of a reference source, his information about Fletcher's tutelage and admission date is very convincing. Not surprisingly, his admission is unstated in the university matriculation records, given their incompleteness, which was quite common in this period. ${ }^{34}$

Furthermore, a John Fletcher, who is recorded as 'Bible clerk' in the Corpus Christi Matriculations Register of 1593, can possibly be identified with John Fletcher, the eye-witness, ${ }^{35}$ for a student quite commonly waited for months or even years after admission to become an official scholarship holder, and, in fact, Fletcher says in the deposition that 'he keepethe in Bennett Colledge $\wedge\ulcorner$ in Camebridge $\urcorner$, and is scholler of the house $\wedge\ulcorner$ there $\urcorner$, and that he lyuethe by the exhibicion that he hathe from his father; ... and by his schollershippe'. ${ }^{36}$ This 'schollershippe' might well be one of the four bible clerkships of Corpus Christi. We may assume, moreover, that Fletcher was hoping to proceed to the degree of MA, judging from the information that he 'kept or remained' in the upper chamber of Dawson and continued to be funded by the college after obtaining his BA. Most likely, therefore, the John Fletcher of Corpus Christi who proceeded to MA in 1598 and John Fletcher the eye-witness were one and the same person. Thus, by adjusting the focus slightly, these blurred figures of Fletcher become one.

Most interesting of all is Fletcher's date and place of birth. The deposition definitely shows that he was born in London ('ibidemque oriundus') in 1576. We may reasonably, therefore, suppose that John Fletcher of Corpus Christi College is not the John Fletcher who was born in Rye 1579. Now we can see how misleading Dyce's eclecticism is. As G.E. Bentley suggests, 'there are various John Fletchers in the registers of Oxford and Cambridge, none of whom can be unquestionably identified as the son of the bishop. The most likely one is "John Fletcher of London," who was admitted pensioner to Bene't College on 15 October 1591'. ${ }^{37}$ Hence, once we accept that John Berkenhead and Thomas Fuller are correct in identifying the playwright with the bishop's son of Rye, we must conclude with Taunton that this Fletcher 
did not follow his father to the college. The Corpus Christi man is not the playwright.

Even so, much remains to be done to solve the problem of why Moseley and his contemporaries considered Fletcher to have been a university-trained playwright and dead at the age of forty-nine. Should we dismiss Humphrey Moseley as flatly (and unfairly) as Dyce and others do? To be sure, some doubted Moseley's competence as an editor. For instance, Sir Aston Cokain, in an epigram addressed to Moseley in Small Poems of Divers Sorts (1658), blames him for not having ascribed to each of the authors his due:

In the large book of Playes you late did print

(In Beaumonts and in Fletchers name) why in't

Did you not justice? give to each his due?

For Beaumont (of those many) writ in few:

And Massinger in other few; the Main

Being sole Issues of sweet Fletchers brain.

But how came I (you ask) so much to know?

Fletchers chief bosome-friend inform'd me so. ${ }^{38}$

What is significant here, however, is that Cokain, informed as he was by 'Fletchers chief bosome-friend', remained silent about Moseley's statements concerning the early years of the poet. Cokain might have overlooked the matter, or even known nothing about it, despite all of his close connections with Philip Massinger and other playwrights, but more likely Cokain considered Moseley's statements to have veracity and to resonate with what had been talked about at that time. Moseley was placed in a situation sufficiently 
playwright: the university-trained man who died at the age of forty-nine. In addition, the traces of the source on which Berkenhead and Fuller rely seem to be too faint to allow satisfactory recognition. Nevertheless, these factors alone are not good enough reasons to question the authenticity of their account. At the same time, the whole of Cambridge and of Oxford would be open to hunt for another candidate if Richard Fletcher the bishop who had an association with Corpus Christi College is no longer regarded as the playwright's father. In order to consider the Corpus Christi man as the playwright, however, scholars would have to prove that the signature of John Fletcher of Corpus Christi College was indeed his. ${ }^{40}$

In the Deposition Book which contains the testimony in the case of Field v. Dawson, each deposition has a signature of the deponent at the end. After confirming the record of his or her statement, the deponent would put a signature, or, when unable to affix his or her signature for some reason (on account of illiteracy, perhaps), a mark, such as a cross or scissors, under the 'signum' given in the document. ${ }^{41}$ Possibly in accordance with this custom, John Fletcher wrote his name, as other deponents did. As for the autograph of the playwright, we have one in the only extant letter from him, addressed to Elizabeth Hastings, the fifth countess of Huntington. ${ }^{42}$ If this letter, as Gordon McMullan suggests, can be dated 'probably from as late in his career as 1620', then the signature at the end should be that of the poet in his forties. ${ }^{43}$ No one can say for certain whether graphological analysis would allow a comparison of the signature of the young student with that of the middle-aged man; so scholars have no way of confirming whether or not the two signatures are in the same handwriting. This matter has to be left to the judgment of handwriting experts. But to ignore this possible but elusive clue for identifying the playwright would be unfair.

At this point, it is very difficult to draw a valid conclusion about the identity of the playwright. The scarcity of primary documents prevents our associating him directly with either the John Fletcher of Corpus Christi or the John Fletcher of Rye. This evidentiary gap seems always to have been the case: conflicting information was possibly the reality from the start, partly because memories of the playwright had faded quickly and partly because a 'myth-making instinct', as Taunton suggests, had been 'in operation down through the generations. ${ }^{44}$ What does seem convincing is that John Fletcher of Corpus Christi College can be distinguished from John Fletcher of Rye, which would contribute to removing the confusion that has blighted efforts to establish the playwright's identity. Biographical facts about the playwright 
are still too scarce to gain a proper understanding of his formative years. Rather than construct one putative 'truth' based on multifarious hypotheses with scanty evidence, we should instead construe scanty evidence with historical truthfulness to advance a very few possible hypotheses.

\section{Notes}

Palaeographical marks include ${ }^{\circ}$ for script in another hand (interpolation), [ ] for cancelled text, $\wedge$ for interpolations, \ulcorner\urcorner half brackets for interlineations above the line by the original scribe, and $\langle\ldots\rangle$ for illegible text. Italics indicate expansions from the abbreviation to the full word. Parentheses and carets are part of the original manuscript. Regular ellipsis ... means editorial omission.

The writing of this article was made possible largely through grants from The Grants-in-Aid for Scientific Research of the Japan Society for the Promotion of Science. I am deeply grateful to the anonymous reviewer at Early Theatre for helpful suggestions. Also I would like to express my gratitude to the librarians of Cambridge University Archive and of the Parker Library at Corpus Christi College, Cambridge.

1 Comedies and Tragedies Written by Francis Beaumont and Iohn Fletcher (London, 1647), A4v.

2 Ibid.

3 Ibid.

4 Andrew Clark (ed.), 'Brief Lives', Chiefly of Contemporaries, Set Down by John Aubrey, Between the Years 1669-1696, 2 vols (Oxford, 1898), 1.95.

5 Hilton Kelliher, 'Francis Beaumont and Nathan Field: New Records of Their Early Years', Peter Beal (ed.), English Manuscript Studies 1100-1700, Volume 8: Seventeenth-Century Poetry, Music and Drama (London, 2000), 28. See also Charles Cathcart, 'John Fletcher in 1600-1601: Two Early Poems, an Involvement in the "Poets' War," and a Network of Literary Connections', Philological Quarterly 81 (2002), 33-51, for a discussion of the possibility that John Fletcher may have had a connection with John Weever of Queens' College, Cambridge.

6 Comedies and Tragedies, E2v. P.W. Thomas points out that Laudians were prominent among the contributors to the works. See his Sir John Berkenhead 1617-1679: A Royalist Career in Politics and Polemics (Oxford, 1969), 135.

7 Thomas gives attention to Berkenhead's propagandist attitude in portraying Fletcher as a royalist poet (Sir John Berkenhead, 134-5). On Berkenhead's 'misogynist fantasy', see Jeffrey Masten, Textual Intercourse: Collaboration, Authorship, and Sexualities in Renaissance Drama (Cambridge, 1997), 134-8. On the royalist project 
of Humphrey Moseley, see Arthur F. Marotti, Manuscript, Print, and the English Renaissance Lyric (Ithaca, 1995), 259-65, and Douglas A. Brooks, From Playhouse to Printing House: Drama and Authorship in Early Modern England (Cambridge, 2000), 140-88.

8 Thomas Fuller, The History of the Worthies of England (London, 1662), 288, in the section of 'Northampton-shire'.

9 Gerald Langbaine, An Account of the English Dramatick Poets (Oxford, 1691), 205-6.

10 Robert Masters, The History of the College of Corpus Christi and the Blessed Virgin Mary in the University of Cambridge (Cambridge, 1753), 288.

11 Nina Taunton, 'Did John Fletcher the Playwright Go to University?' Notes and Queries 37 (1990), 172.

12 For information on the students and fellows of Cambridge, I am greatly indebted to John Venn and J.A. Venn, Alumni Cantabrigienses: Part I, from the Earliest Times to 1751, 4 vols (Cambridge, 1922), and John Lamb, Masters' History of the College of Corpus Christi (London, 1831).

13 Alexander Dyce, 'Some Account of the Lives and Writings of Beaumont and Fletcher', Alexander Dyce (ed.), The Works of Beaumont and Fletcher, 11 vols (London, 1843-6), 1.xviii.

14 Patrick Collinson, 'Cranbrook and the Fletchers: Popular and Unpopular Religion in the Kentish Weald', in his Godly People: Essays on English Protestantism and Puritanism (London: 1983), 418-23.

15 Historical Manuscripts Commission, Thirteenth Report, Appendix, Part IV: The Manuscripts of Rye and Hereford Corporations (London, 1892), 52. Roger B. Manning points out that "Fletcher was still preaching at Rye in May 1582', based on a certificate sent to the bishop of Chichester by the mayor and jurats of Rye: 'Doctor Fletcher, chancellor of this diocese: since the time of his coming to the office of Chancellorship had dealt very justly and uprightly in the execution thereof and therefore as he hath deserved great love among us, so we heartily desire he may long time abide and continue in this diocese, to the glory of God and the benefit of this country'. See HMC, Thirteenth Report, Appendix, Part IV, 81; Roger B. Manning, Religion and Society in Elizabethan Sussex (Leicester, 1969), 78, n.1, and Graham Mayhew, Tudor Rye (Falmer, 1987), 129-33.

16 Lloyd E. Berry, 'Biographical Notes on Richard Fletcher', Notes and Queries 7 (1960), 377-8.

17 Dyce, Works of Beaumont and Fletcher, 1.xviii, note q.

18 Ibid, xviii.

19 For example, see Charles Mills Gayley, Beaumont, the Dramatist (New York, 1914), 62-3; Lawrence B. Wallis, Fletcher, Beaumont and Company (New York, 1947), 
142-4; Gerald Eades Bentley, The Jacobean and Caroline Stage, 7 vols (Oxford, 1956), 3: 306; Gordon McMullan, The Politics of Unease in the Plays of John Fletcher (Amherst, 1994), 11, and elsewhere.

20 See Lawrence Stone, 'The Size and Composition of the Oxford Student Body 15801910', Lawrence Stone (ed.), The University in Society Vol. I: Oxford and Cambridge from the 14th to the Early 19th Century (Princeton, 1974), 29-33.

21 E.K. Chambers, The Elizabethan Stage, 4 vols (Oxford, 1923), 3.314. See also Una Ellis-Fermor, The Jacobean Drama (London, 1936), 309.

22 Taunton, 'Did John Fletcher the Playwright Go to University?', 172.

23 This point is argued in my article, 'Christopher Marlowe, William Austen, and the Community of Corpus Christi College', Studies in Philology 104 (2007), 56-81. For the history and business of the vice-chancellor's court, see Heather Peek and Catherine Hall, The Archives of the University of Cambridge (Cambridge, 1962); Alexandra Shepard, 'Legal Learning and the Cambridge University Courts, c. 1560-1640', Legal History 19 (1988), 62-74; and her 'Contesting Communities?: "Town" and "Gown" in Cambridge, c. 1560-1640', Alexandra Shepard and Phil Withington (eds.), Communities in Early Modern England: Networks, Place, Rhetoric (Manchester, 2000), 216-34; and Victor Morgan, A History of the University of Cambridge Volume II 1546-1750 (Cambridge, 2004), 88-96.

24 The following description of the incident is based on the depositions of litigants and those who were involved in the Field v. Dawson lawsuit: see Cambridge University Archive, V. C. Ct. II. 1. Depositions (9 July 1593-2 April 1597), Ralph Dawson (198r-v, 202r-203r, 204r-v), Nicholas Martin (198v-200v), John Fletcher (200v201v), Thomas Field (203r-204r), Thomas Brookes (206r-208r), and John Smith (205r-206r).

25 CUA, V. C. Ct. II.1, 202v-203r.

26 According to the deposition drawn up on 12 December 1595, Nicholas Martin, MA, came from Teigh in Rutland and was twenty-three years old at that time. $\mathrm{He}$ had been in Corpus Christi for over seven years and had been a fellow since 1594 . Before coming to Cambridge, he had lived in London for seven years. Martin says in his deposition that 'Mr ffeilde is of this deponents [ie, Martin's] acquaintance and his friend'. CUA, V. C. Ct. II.1, 198v, 200r.

27 CUA, V. C. Ct. II.1, 199r-v.

28 Ibid. As for Dawson's coercive measures, see also Thomas Brookes's deposition: CUA, V. C. Ct. II.1, 207r.

29 It is not unusual to come across lawsuits for preserving one's reputation in the vicechancellor's court records. For a student whose livelihood was based on his credit, injuries against his reputation would have entailed depriving him of his capital. The 
threat to his reputation was so serious as to cause a mere student to turn to the law. Craig Muldrew cogently argues about the cultural context of credit in The Economy of Obligation: The Culture of Credit and Social Relations in Early Modern England (Basingstoke, 1998), chap. 5.

30 CUA, V. C. Ct. II.1, 205r-v. These two actions recorded by John Smith can be found in CUA, V. C. Ct. I. 30, $171 \mathrm{r}$.

31 CUA, V. C. Ct. II.1, 204r-v.

32 CUA, V. C. Ct. II.1, 201r-v. The records concerning Fletcher's appearance as a witness at the vice-chancellor's court can be found in CUA, V. C. Ct. I. 30, 192r, 195 r.

33 CUA, V. C. Ct. II.1, 200v.

34 Peek and Hall, Archives of the University of Cambridge, 31.

35 For a John Fletcher who was described as a 'Bible clerk', see Masters, History of the College of Corpus Christi, 288, and Taunton, 'Did John Fletcher the Playwright Go to University?', 172.

36 CUA, V. C. Ct. II.1, 201v.

37 Bentley, Jacobean and Caroline Stage, 3. 306.

38 Sir Aston Cokain, Small Poems of Divers Sorts (London, 1658), 117 (P5r). Similar complaints may be observed in Abraham Cowley, Poems (London, 1656), 'Preface of the Author', alv-a2r.

39 Robert K. Turner, 'The Folio of 1647', Fredson Bowers (ed.), The Dramatic Works in the Beaumont and Fletcher Canon (Cambridge, 1966), 1. xxvii-xxviii.

40 As for the autograph of John Fletcher of Corpus Christi College, see CUA, V. C. Ct. II.1, 201v.

41 For instance, see CUA, V. C. Ct. II.1, 174v, 178v, 199r, etc.

42 As for the autograph of the playwright, see W.W. Greg, English Literary Autographs 1550-1650 (Oxford, 1931), pt. III, xciii.

43 McMullan, Politics of Unease, 17.

44 Nina Taunton, 'Biography, a University Education, and Playwriting: Fletcher and Marlowe', Research Opportunities in Renaissance Drama 33 (1994), 64. 